\title{
Research on Design Method Optimization of Combined Sewer Overflow Detention Tank
}

\author{
Tang Lei ${ }^{1,}$, , Jia Shuhui ${ }^{1}$, Wang Weiwei ${ }^{1}$, Wu Song ${ }^{2}$, Yi Qingsong ${ }^{2}$ \\ ${ }^{1}$ Water \& Infrastructure Institute, China Academy of Urban Planning \& Design, Beijing, China \\ ${ }^{2}$ Western Branch, China Academy of Urban Planning \& Design, Chongqing, China
}

Email address:

tanglei_2013@163.com (Tang Lei),398501864@qq.com (Jia Shuhui)

${ }^{*}$ Corresponding author

\section{To cite this article:}

Tang Lei, Jia Shuhui, Wang Weiwei, Wu Song, Yi Qingsong. Research on Design Method Optimization of Combined Sewer Overflow Detention Tank. American Journal of Water Science and Engineering. Vol. 6, No. 1, 2020, pp. 1-9. doi: 10.11648/j.ajwse.20200601.11

Received: December 14, 2019; Accepted: January 3, 2020; Published: January 21, 2020

\begin{abstract}
Detention tank is widely used in urban waterlogging control, rainwater runoff pollution control, combined sewer overflow (CSO) control and rainwater utilization, etc. For detention tanks in different types or functions, their design methods, construction forms and ways of operation and management are very different. In recent years, many cities in China have begun to apply or plan to build CSO detention tanks to control the CSO pollution, but there are still many problems and puzzles in designing the tank. This paper summarizes and evaluates the common design methods of CSO detention tank at China and abroad. Based on the physical projects in which the author has participated in, the scale and control effect of the CSO detention tank are studied by model simulation, taking a combined sewer system catchment in the Beijing old city as examples. Based on the analysis, the long-term simulation method is recommended for designing of CSO detention tanks in China, and a design criteria suitable for a larger range can be determined through research and analysis of a typical and representative area if there is no way to research every area. At last, several key factors that affect greatly the scale and pollutant control efficiency of CSO detention tank are summarized and analyzed, including objectives of CSO control, rainfall characteristics, CSO pollutants transport law, interception multiple, capacity of wastewater treatment plant, space conditions and investment, layout of detention tank and operation mode of detention tank. Hope to provide reference for the scientific designing of CSO detention tank and realize cost-effectively controlling CSO in cities of China.
\end{abstract}

Keywords: Combined Sewer Overflow, Detention Tank, Design Method, Cost-effective, China

\section{Summary of Design Methods of CSO Detention Tank at China and Other Countries}

The application of CSO detention tanks in developed countries has been very extensive and mature. In recent years, many cities in China have begun to apply or plan to build CSO detention tanks [1], but there are still many problems and puzzles in design of CSO detention tank. Although the calculation formula of scale design of CSO detention tank has been provided in the relevant Codes [2], the formula is difficult to meet the actual needs of the projects since the CSO detention tank scale design and control efficiency of CSO pollutants are affected by a lot of factors, besides, there are also huge variations in different cities in China.

The design method of CSO detention tank adopted by some countries or cities are summarized in Table 1. Generally speaking, the developed countries have relatively more mature ideas and methods in design of CSO detention tank. In general, the scale of CSO detention tank is designed according to a relatively clear control objective, such as overflow frequency, overflow amount, CSO amount control and control rate of CSO pollution load, by modeling the drainage network, or by simulating and analyzing a typical area and drawing up correlation curves between the detention amount and control efficiency to choose a rational scale for the detention tank. CSO detention tanks have been built in Shanghai, Kunming and many other cities in China. There are also many reports about their scale design and operation effect of the tanks, such as the five CSO detention tanks along Suzhou River in 
Shanghai. However, most of the CSO detention tanks in China built at early stage were directly referred to foreign formulas and parameters, and the design methods were lack of scientific basis as a whole; with the development of research, some design methods based on rainfall statistical calculation, actual operation effect or model simulation are used in projects.

Table 1. Summary of CSO Detention Tank Design Methods [3-6].

\begin{tabular}{|c|c|c|}
\hline Design method & Country / City & Design method description \\
\hline $\begin{array}{l}\text { Model } \\
\text { simulation }\end{array}$ & U.S.A & $\begin{array}{l}\text { By establishing a drainage network model, the scale of CSO detention tank is determined according to relevant } \\
\text { design criteria or objectives, such as overflow frequency or pollution load reduction target value. The CSO } \\
\text { detention tanks in some cities are designed to detent the CSO under a certain design rainfall for a certain period of } \\
\text { time, such as "to detent the CSO for the first } 30 \text { minutes of once every } 10 \text {-year rainfall event". }\end{array}$ \\
\hline $\begin{array}{l}\text { Calculation } \\
\text { formula }\end{array}$ & Germany & $\begin{array}{l}\text { According to CSO control objective of "the load of the combined sewer system discharging into the water body is } \\
\text { no greater than that of the divided sewer system", the scale of the detention tank is determined in combination with } \\
\text { the relevant parameters of the drainage system. The simplified calculation formula is: } V=1.5 \cdot V_{S R} \cdot A_{U} \text {, where } V \text { is } \\
\text { the volume of detention tank }\left(\mathrm{m}^{3}\right) ; V_{\mathrm{SR}} \text { is the amount of rainwater to be detained per hectare }\left(\mathrm{m}^{3} / \mathrm{ha}\right) \text {, which is } \\
\text { generally } 12 \leq V_{S R} \leq 40 \text { in Germany; and } A_{U} \text { is the area of non-permeable. }\end{array}$ \\
\hline $\begin{array}{l}\text { Model } \\
\text { simulation }\end{array}$ & Japan & $\begin{array}{l}\text { According to pollution reduction objective of "the pollution load discharged by the combined sewer system is no } \\
\text { greater than that of the divided sewer system", and based on the simulation test, the correlation between the } \\
\text { intercepting amount and the scale of the detention tank is studied, and then the rational volume of the CSO } \\
\text { detention tank is determined through the evaluation of the actual application effect. }\end{array}$ \\
\hline $\begin{array}{l}\text { Model } \\
\text { simulation }\end{array}$ & Italy & $\begin{array}{l}\text { The drainage model is used to simulate the operation of the CSO detention tank. By analyzing the correlation } \\
\text { between different control volumes and control efficiency, it can find that the scale of detention tank in a certain } \\
\text { range can achieve relatively high control efficiency. }\end{array}$ \\
\hline $\begin{array}{l}\text { Calculation } \\
\text { formula }\end{array}$ & $\begin{array}{l}\text { Code for design of } \\
\text { outdoor drainage } \\
\text { in China }\end{array}$ & $\begin{array}{l}V=3600 t_{i}\left(n-n_{0}\right) Q_{d r} \cdot \beta \text {, where } V \text { is the effective volume of the detention tank }\left(\mathrm{m}^{3}\right), t_{i} \text { is the inflow time of the } \\
\text { detention tank }(\mathrm{h}), n \text { is the interception multiple during the operation of the detention tank, } n_{0} \text { is the original } \\
\text { interception multiple of the system, } Q_{d r} \text { is the wastewater rate in dry days before intercepting }\left(\mathrm{m}^{3} / \mathrm{s}\right) \text {, and } \beta \text { is the } \\
\text { safety factor. }\end{array}$ \\
\hline $\begin{array}{l}\text { Calculation } \\
\text { formula }\end{array}$ & $\begin{array}{l}\text { Shanghai } 1 \\
\text { (China) }\end{array}$ & $\begin{array}{l}\text { Using the German calculation formula as reference, where } V_{S R} \text { is taken as } 20 \mathrm{~m}^{3} / \text { ha; for several later built detention } \\
\text { tanks in Shanghai, the value taken for the design detention capacity have been increased. }\end{array}$ \\
\hline $\begin{array}{l}\text { Calculation } \\
\text { formula }\end{array}$ & $\begin{array}{l}\text { Shanghai } 2 \\
\text { (China) }\end{array}$ & $\begin{array}{l}\text { The calculation formula of the interception volume of the detention tank is } V=60 Q \cdot t \text {, where } V \text { is the volume of } \\
\text { detention tank }\left(\mathrm{m}^{3}\right), Q \text { is the interception multiple of sewer system }\left(\mathrm{m}^{3} / \mathrm{s}\right), t \text { is the interception time }(\mathrm{min}) \text {, and the } \\
\text { interception time is taken as } 75,60 \text { or } 100 \text { min respectively. }\end{array}$ \\
\hline $\begin{array}{l}\text { Statistical } \\
\text { calculation of } \\
\text { rainfall }\end{array}$ & $\begin{array}{l}\text { Shanghai } 3 \\
\text { (China) }\end{array}$ & $\begin{array}{l}\text { According to rainfall amount } p \text {, rainfall duration } t \text { and land use type, residual sewer interception capacity of the } \\
\text { drainage system } P \text {, the Event Mean Concentration }(E M C) \text { of detention and overflow period, the annual overflow } \\
\text { amount or overflow pollutant reduction rate corresponding to different detention amount is calculated, and then the } \\
\text { detention tank volume } V \text { is calculated according to the objective set by the overflow pollutants reduction rate. }\end{array}$ \\
\hline $\begin{array}{l}\text { Model } \\
\text { simulation }\end{array}$ & Hefei (China) & $\begin{array}{l}\text { Continuous simulation of all rainfall events in a typical year shows that the combined sewer system can reduce the } \\
\text { overflow amount by } 45 \% \text { and the overflow frequency by } 61 \% \text { in a average year when the volume of } 4 \mathrm{~mm} \text { runoff } \\
\text { depth is adopted in the detention tank under the condition of twice the current interception multiple. }\end{array}$ \\
\hline
\end{tabular}

To sum up, the designing of a CSO detention tank usually needs to get the control effect under different design scales, combining with the local CSO control objectives to make decisions. According to the conditions of the project and the information obtained by the author, in this work the combined sewer system of the old urban part of Beijing city was taken as an example to study the scale and control effect of the CSO detention tank by means of model simulation.

\section{Simulation of the Scale and Control Effect of CSO Detention Tank - with Beijing Old City as an Example}

\subsection{Brief of the Researched Area}

In order to reduce the CSO pollution discharged into the receiving water body (mainly the Beijing Moat) in rainy days, Beijing plans to build multiple CSO detention tanks in the combined sewer system area, and one of the proposed CSO detention tanks called L pumping station catchment located near the overflow outlet at the downstream of the catchment area is studied. Figure 1 shows the location and catchment range of the proposed CSO detention tank, which is located in the east section of Longtan Road, close to the southeast Beijing Moat, and there is a $2600 \mathrm{~mm} \times 2650 \mathrm{~mm}$ combined square sewer under Longtan Road.

The wastewater flow in dry days of the proposed detention tank is intercepted to Gaobeidian wastewater treatment plant through Nanbinhe Road main pipeline, and the combined wastewater directly flows into the southeast Beijng Moat in rainy days.

The catchment area of the detention tank includes 6 small basins (see Figure 2). It is planned to collect the combined wastewater in these 6 small basins to the detention tank through newly built or expanded intercepting pipeline. The combined sewer exceeding the capacity of the detention tank will directly overflow into the water body. The red part in Figure 3 is the pipelines in the catchment area of the drainage model. Table 2 shows the relevant information of the catchment of the CSO detention tank. 


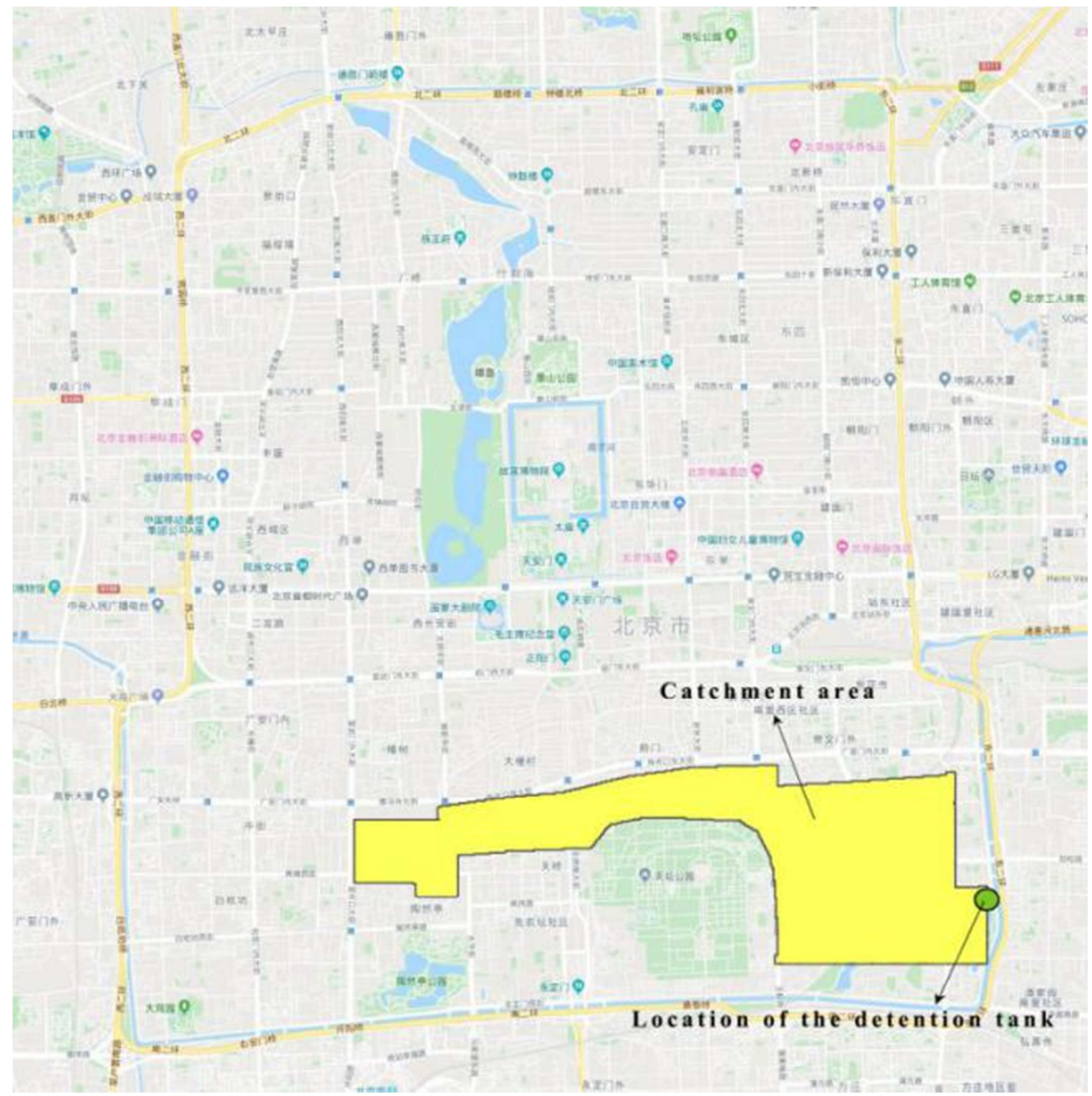

Figure 1. Location and catchment area of the CSO detention tank.

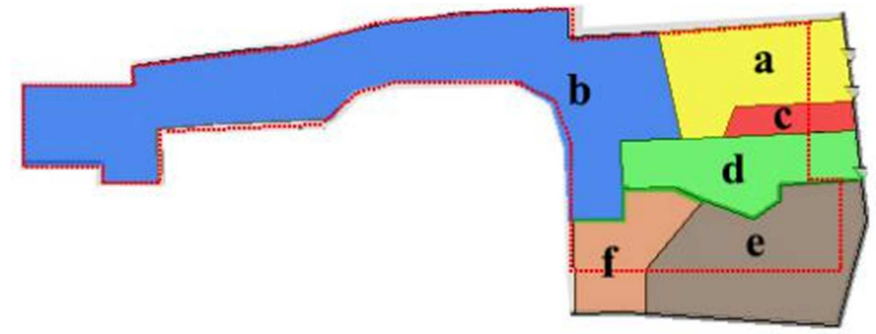

Figure 2. Basins of the CSO detention tank catchment.

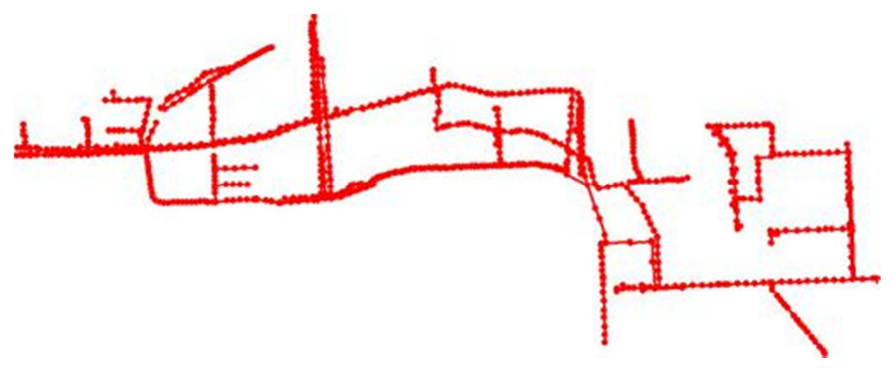

Figure 3. Pipelines of the catchment in the model. 
Table 2. Related information of the CSO detention tank catchment in Beijing old city.

\begin{tabular}{|c|c|c|c|c|c|c|c|}
\hline Basin number Basin information & $\mathbf{a}$ & b & $\mathbf{c}$ & d & e & f & Sum \\
\hline Basin area (ha) & 80.25 & 290.92 & 39.72 & 48.40 & 118.21 & 33.12 & 610.62 \\
\hline $\begin{array}{l}\text { Proportion included in the scope of catchment of the } \\
\text { detention tank }\end{array}$ & About $80 \%$ & $100 \%$ & About $60 \%$ & About $80 \%$ & About $50 \%$ & About $30 \%$ & - \\
\hline Area included in the catchment of the detention tank (ha) & 64.20 & 290.92 & 23.83 & 38.72 & 59.11 & 9.94 & 486.71 \\
\hline
\end{tabular}

\subsection{Long-term Simulation Analysis Based on Actual Rainfall Data}

\subsubsection{Simulation Methods and Results}

In this work, the catchment area of L pumping station was taken as an example to analyze the design scale and control effect of CSO detention tank by model ((InfoWorks) simulation. The simulation method is based on the long-term simulation of the historical rainfall records to accomplish the statistical analysis of the overflow under the continuous actual rainfall conditions.

With all available information, the actual rainfall data of the monitoring station located in the researched area from June to August in 2011 were used to simulate the researched area and analyze the CSO situation of the pipeline at the end of the researched area. Because the rainfall in Beijing is mainly concentrated in the flood season from June to August, it can be considered that there is no production of overflow in other months due to low rainfall intensity. Therefore, although only three months' rainfall data are used in the model simulation, the results can be approximately considered to be more accurate in terms of reduction in overflow times and the reduction in overflow amount. In this study, 4 hours was took as the minimum time interval to divide two rainfalls, and any single rainfall less than $0.5 \mathrm{~mm}$ is ignored, therefore it is concluded that there are 28 rainfalls in the researched area from June to August 2011, with a typical total rainfall of $546.5 \mathrm{~mm}$, which is close to the multi-year average value. After analyzing the rainfall data, the rainfall events with rainfall over $1 \mathrm{~mm}$ are brought into the model for calculation (23 events in total); according to the flow volume of the main combined pipes in dry days in the model, the interception capacity of the downstream intercepting pipeline is about $0.45 \mathrm{~m}^{3} / \mathrm{s}$, which is calculated according to the interception multiple 3 ; it is assumed that the combined wastewater exceeding the interception capacity of the intercepting pipe enters the detention tank first, and then overflows until the detention tank is full, and the detention tank can be drained in time without affecting the following use. Figure 4 shows the long-term simulation results of the overflow process in the researched area from June to August 2011.

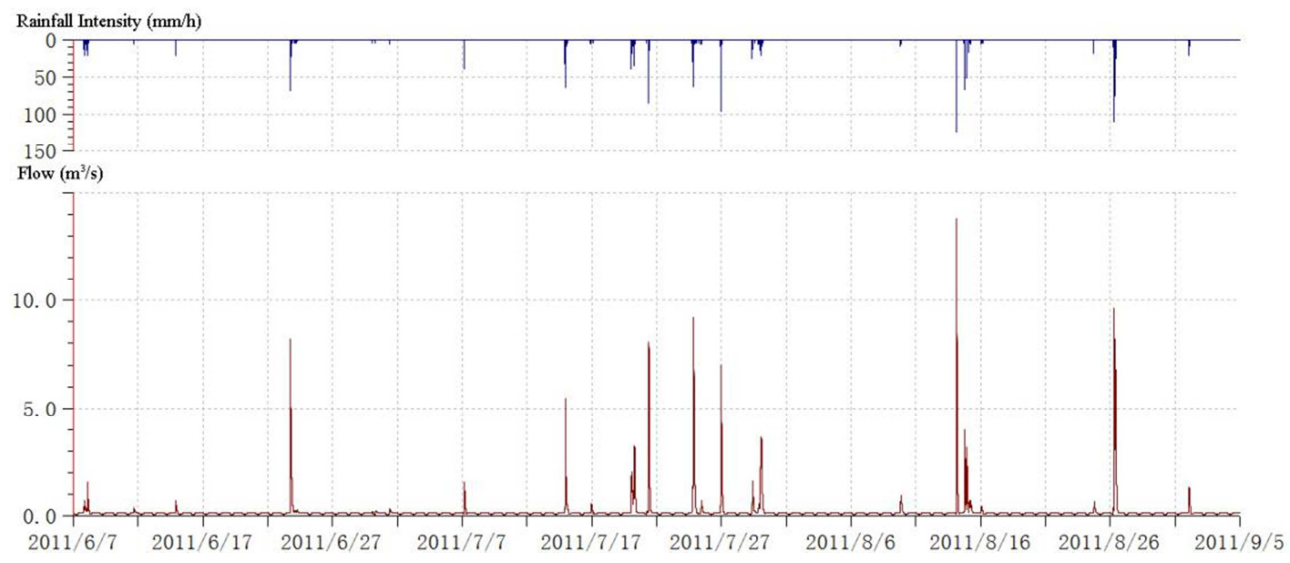

Figure 4. Overflow process of the catchment from June to August, 2011.

\subsubsection{Analysis of the Simulation Results}

According to the statistical results, 18 of the 23 rainfalls input into the model have overflowed in the current sewer system condition, among which part of the rainfalls have multiple overflow events, which is calculated as one overflow event in the statistics.

The actual control effect of different design scale is shown in table 3. As can be seen from the data, when the design detention capacity is $10 \mathrm{~mm}$, the reduction rate of overflow amount and overflow times can reach about 50\% - 60\%, which is the value recommended to be taken.

Table 3. Modeling control effect under different size of detention tank.

\begin{tabular}{|c|c|c|c|c|c|}
\hline \multirow{2}{*}{$\begin{array}{l}\text { control effect Design detention capacity } \\
(\mathrm{mm})\end{array}$} & \multicolumn{3}{|c|}{ Reduction of CSO amount } & \multicolumn{2}{|c|}{ Reduction of CSO times } \\
\hline & m3 & $\mathbf{m m}$ & Reduction ratio & times & Reduction ratio \\
\hline 2 & 90155 & 28.5 & $18.8 \%$ & 8 & $44.4 \%$ \\
\hline 4 & 153427 & 48.5 & $32 \%$ & 8 & $44.4 \%$ \\
\hline 6 & 216699 & 68.5 & $45.3 \%$ & 8 & $44.4 \%$ \\
\hline
\end{tabular}




\begin{tabular}{llllll}
\hline \multirow{2}{*}{$\begin{array}{l}\text { control effect Design detention capacity } \\
(\mathbf{m m})\end{array}$} & \multicolumn{2}{l}{ Reduction of CSO amount } & \multicolumn{2}{c}{ Reduction of CSO times } \\
\cline { 2 - 6 } & $\mathbf{m 3}$ & $\mathbf{m m}$ & Reduction ratio & times & \multicolumn{2}{c}{ Reduction ratio } \\
\hline 8 & 274893 & 86.9 & $57.4 \%$ & 9 & $50 \%$ \\
10 & 328801 & 103.9 & $68.7 \%$ & 11 & $55.6 \%$ \\
15 & 405793 & 128.3 & $84.7 \%$ & 14 & $77.8 \%$ \\
20 & 457799 & 144.7 & $95.6 \%$ & 17 & $94.4 \%$ \\
25 & 473617 & 149.7 & $98.9 \%$ & 17 & $94.4 \%$ \\
30 & 478876 & 151.4 & $100 \%$ & 18 & $100.0 \%$ \\
\hline
\end{tabular}

\subsection{Analysis of the Model Simulation Method and Results}

Because of the lack of construction \& operation experience and actual monitoring data of CSO detention tank in Beijing, the accuracy of the results obtained by the above model simulation method may be questionable, but the conclusions obtained by the this method is still of great reference value to the engineering practice in the condition that more detailed basic information was unable to obtain. The general idea of the method is based on the working principle of CSO detention tank (Figure 5), through simulation and calculation, and the overflow amount is statistically analyzed to obtain the corresponding control effect under different design detention capacity.

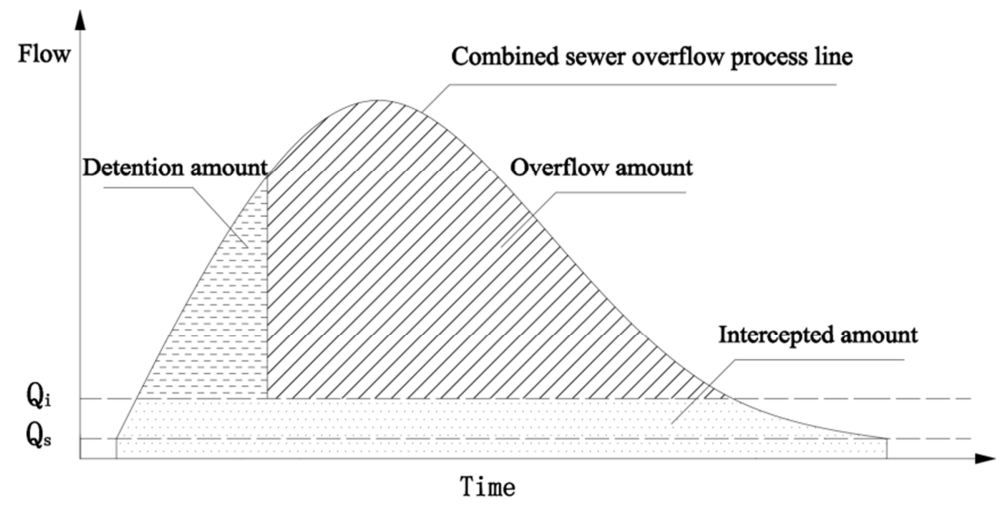

Figure 5. Working principle schematic diagram of CSO detention tank.

Meanwhile, there are also some problems and defects with the calculation principle and hypothesis conditions of the model simulation method: although the model has been verified, it still does not exclude the influence of uncertain factors, and the simulation results lack the support of measured data; without considering the operation mode of the pumping station and the detention tank, it is assumed that all CSO enters the detention tank first and then can be drained out in time.

Table 4 shows the actual operation effect of CSO detention tanks along Suzhou River in Shanghai. The size of each detention tank is converted "designed detention capacity" correspondingly in this study. The comparison between the actual operation effect of those tanks in Shanghai and the simulation control effect of $\mathrm{L}$ pumping station detention tank shows that some of the results are close to each other, while some of the results are quite different. This may be closely related to different regions, different rainfall characteristics, different interception times and other factors, which will be analyzed in details later in future research.

Table 4. Practical operation effects of the five CSO detention tanks along Suzhou River in Shanghai.

\begin{tabular}{|c|c|c|c|c|c|}
\hline \multirow{2}{*}{ Statistical parameter } & \multicolumn{5}{|c|}{ Name of detention tank } \\
\hline & Chengdu Road & New Changping & Mengqing garden & Jiangsu Road & Furong River \\
\hline Converted to design detention capacity (mm) & 3 & 6.6 & 15.76 & 4.05 & 3 \\
\hline five CSO detention tanks along Suzhou Rive & 9.8 & 31.0 & 78.8 & 34.3 & 13.9. \\
\hline $\begin{array}{ll}\text { Reduction rate } & \text { The simulation control effect of Beijing old city } \\
\text { of CSO (\%) } & \text { detention tank under the corresponding } \\
& \text { designed detention capacity }\end{array}$ & 25.4 & 48.9. & 86.4 & 32.3. & 25.4. \\
\hline
\end{tabular}

\subsection{Recommended Method for Design of CSO Detention Tank}

In general, long-term simulation or typical rainfall simulation with drainage model is a common method for the design of CSO detention tank scale, which is widely used in many developed countries. Based on the analysis of this study, the long-term simulation method is recommended for designing of CSO detention tanks in China. The actual rainfall over many years or in a typical year can be simulated by modeling the researched area. If it is not possible to study every area, the typical and representative area can be selected, and a design criteria suitable for a larger range can be determined through research and analysis. In addition, if the time, technology and financial conditions are good, and enough basic data and information are available, it is suggested to carry out systematic simulation (comprehensive 
simulation of water quantity and quality) and dynamic simulation (combined with the actual operation of pumping stations and detention tanks) in order to improve the accuracy of the results.

For the area without conditions to build a drainage model, statistical calculation and the calculation formula in the design code can be used as a reference, and the simulation results or the actual operation results of relevant cities can be referenced. However, it needs to be determined after analyzing and studying the conditions of the city itself, and directly using a calculation formula or design parameters for design should be avoided. It should be noted that the parameter values, namely the determination of the inflow time of the detention tank, the interception multiple $n$ during the operation of the detention tank and the safety factor $\beta$, in the calculation formula for the scale of CSO detention tank given in the Code for Design of Outdoor Drainage may be inaccurate, which leads to the lack of accuracy of the calculation results.

\section{Key Factors Affecting the Scale Design and Pollutants Control Efficiency of CSO Detention Tank}

The research on correlation between detention capacity and control effect of CSO detention tank is only an important part of sizing a detention tank, which is also closely related to local rainfall characteristics, wastewater flow in dry days, capacity of the interception pipeline, type of land use, catchment area and other factors. In practice, the determination of detention tank scale should also take the CSO control objectives, the treatment capacity of the wastewater treatment plant, and the space conditions of the site into consideration. The improvement of the control efficiency of detention tank, especially the improvement of the pollutants removal rate, not only depends on the rational design of the scale of the detention tank, but also involves many key factors, such as the CSO pollutants transport law, the layout of the detention tanks, the operation mode of the detention tank, and the real-time control technology.

\subsection{Objectives of CSO Control}

Generally speaking, CSO pollution status and control objectives directly affect or determine the scale of CSO control measures. The design of the tank scale is usually based on CSO control objectives in some countries. However, many cities in China have not yet formulated a clear goal of CSO control, which affects the formulation of CSO control plan and the determination of the scale of detention tank [7,8].

The CSO control objectives in developed countries include reduction of overflow in amount and times, reduction of total overflow pollutants, control of rainfall events in a certain recurrence period, or "combined sewer system pollution load equals to that of separate sewer system", all of which are based on achieving or upgrading the water quality of the receiving water to a certain target. The determination of CSO control objectives has the following characteristics $[9,10]$ :

a) The objectives set by different departments may be different, such as that EPA and DEQ in United States have different requirements;

b) The objectives set at different levels may be different, such as that national standards, local standards or specific projects may be different;

c) The objectives set at different stages may be different, for example, the Tokyo CSO control has clear short-term, medium-term and long-term objectives;

d) There may be several parallel objectives, such as the control objectives of the United States and Japan are all parallel and from different angles.

\subsection{Rainfall Characteristics}

Rainfall conditions such as total annual rainfall, rainfall distribution, rainfall intensity and rainfall type are closely related to the scale design, operation efficiency and investment cost of CSO detention tank. Different rainfall characteristics in different cities may lead to significant differences in the scale and effect of control facilities. For example, the design of CSO detention tank on Chengdu Road in Shanghai directly refers to the design method and design parameters of the detention tank in Germany. However, due to the small difference between the average monthly rainfall and the long duration of a single rainfall in Germany, while most of the rainfall in Shanghai is concentrated in the flood season from June to September and there are many rainstorms, the actual control effect of Chengdu Road CSO detention tank is very low.

The collection and selection of rainfall data also have a great influence on the determination of the scale of the CSO detention tank. In the process of simulation, selecting rainfall data of different years may have a greater impact on the results, especially on the simulation results of wet and dry years. The number of years of rainfall data will also significantly affect the statistical results, for example, some cities may have consecutive years of drought such as Beijing in the past decade or consecutive years of rainy.

\subsection{CSO Pollutants Transport Law}

According to the relevant research of the author [11], under the comprehensive influence of rainfall conditions, drainage system characteristics, pipeline sediment conditions, interception facilities and other factors, the results of CSO first flush monitored by different researched areas, rainfall conditions and pollutant indicators are quite different, even the first flush of each drainage system in different rainfall events may be different. Therefore, the design scheme and parameters should be based on the monitoring and research of the area, and scientifically disclosing the essence and characteristics of CSO first flush, rather than the assumptions on CSO first flush. Different first flush in different areas will inevitably lead to significant differences in the control effect of the detention tank.

The large catchment area, complex network topology, a large 
number of pipeline sediments and the setting of interception facilities in the combined system impaired first flush of CSO, resulting in the general non obvious first flush of CSO and possible occurrence of the "last flush ". If the CSO discharge has obvious first flush, the large pollutant control amount can be achieved by controlling a small amount of initial overflow water, so as to improve the control efficiency; if the first flush does not exist or is not obvious, i.e. the overflow pollution load is discharged evenly, it can be approximately considered that the overflow pollutant reduction rate increases linearly with the increase of detention amount in a certain range; if there is "last flush " in the overflow process, the pollutant control efficiency of the operation mode of storing the initial overflow sewer will be greatly reduced.

\subsection{Interception Multiple}

In different cities or areas, even with the same scale of a CSO detention tank, the control effect (reduction rate of overflow amount, etc.) is often quite different, which may be closely related to the dry wastewater flow in dry days and interception multiple of the combined system. It is of great practical significance to study the control effect of CSO under different interception multiple and different detention scales. The research conclusion can provide guidance for the cities that are carrying out wastewater interception projects and constructing detention tanks, choosing the more economical and reasonable scheme between increasing interception multiple and adopting detention facilities according to the combination of research results and economic cost analysis, or choosing the interception and detention scales more reasonably.

The statistical calculation and model simulation of the annual runoff reduction rate under different interception multiple and designed detention capacity are carried out respectively, the conclusions of which are similar to that of other scholars: due to smaller flow of wastewater in dry days than that of combined wastewater during rainstorm and the low proportion of combined wastewater intercepted by the interception pipeline, it is not obvious to adjust the improvement of the control effect of the detention tank by increasing the interception pipeline in a limited range, especially in the reduction of the number of overflow times. Therefore, in consideration of the poor operability of increasing the interception pipeline in the actual project, it is generally recommended to adopt the current interception pipeline and appropriate detention tank capacity to meet the pollution control objectives.

\subsection{Capacity of Wastewater Treatment Plant}

The function of CSO detention tank is equivalent to improving the interception capacity of the combined system, but it should be noted that the scale design of the detention tank cannot be considered simply from the perspective of increasing the interception multiple. Due to the limited detention and treatment capacity of the wastewater treatment plant, the design of the CSO detention tank also needs to consider the impact on the downstream plant. In order to avoid affecting the normal operation of the detention tank, it is generally necessary to ensure that the detention tank is drained empty in time or treated on site before the next overflow occurs; if it cannot be drained in time or the wastewater treatment plant is unable to process the combined wastewater discharged from the detention tank, a large number of CSO will overflow outside the wastewater treatment plant, then the detention tank won't play a role in reducing CSO pollutants.

Therefore, in order to avoid a large number of CSO overflowing outside the wastewater treatment plant in rainy days, it needs to consider the treatment capacity of the downstream wastewater treatment plant in the design of the CSO detention tank, and the plant itself needs to be able to cope with the increased combined wastewater in rainy days. It can be considered to build a detention tank near the wastewater treatment plant or the main intercepting pipeline leading to the plant to regulate and store the combined wastewater that exceeds the treatment capacity of the plant. After the rain, the combined wastewater stored in the detention tank will be transported to the plant for treatment to make full use of the treatment capacity and increase the utilization rate. Regarding to the combined wastewater that exceeds the treatment capacity of the plant, the detention tank scale near the wastewater treatment plant is mainly determined according to the intercepting flow and the treatment capacity of the plant $[12,13]$.

\subsection{Space Conditions and Investment}

According to the practical experience of relevant projects in Beijing and Shenyang of China, the design of CSO detention tank is usually not just a simple technical problem, sometimes even depends on the determination of the government financial support. As the planning and construction of CSO detention tank are generally located in the old or central urban area, it is difficult to reserve space for the detention tank in advance like the new urban planning, which inevitably faces the problems of land shortage and huge additional investment. When determining the scale of detention tank in a specific scheme, it is necessary to consider the space conditions, funds and control objectives. Theoretically, the larger the detention volume is, the higher the reduction rate of overflow amount and overflow pollution load will be. However, the rate of improvement of CSO reduction rate and the engineering cost of the detention tank should also be considered.

\section{Key Factors Affecting Pollutant Control Efficiency of CSO Detention Tank}

\subsection{Layout of Detention Tank}

The layout of the detention tanks, at the end of the catchment or at the middle, centralized or decentralized, online or offline, etc. is closely related to the control efficiency of CSO. On the other hand, the functions (pollution control or flood control) and their effects of the detention tanks at 
different locations are also different.

There may be serious waterlogging problems in the combined sewer regions, and waterlogging problems and pollution problems are usually intertwined and affected each other. In this case, CSO control and waterlogging control need to be considered comprehensively in design of detention tank. According to the control objectives and space conditions, the detention tank can be set at the end or middle of the combined sewer system. The end detention tank is mainly used for CSO control, which has little effect on improving the drainage ability of the system and the operation condition of the pipe network; while the detention tank used to improve the drainage ability of the downstream of the system is generally set in the upstream or middle of the system, which can solve the overload condition of the pipe network system. The middle position detention tank can used for CSO pollution control if the CSO water in the detention tank can be treated or transported to the wastewater treatment plant after rain. If the CSO wastewater stored in the detention tank can be treated and reused after the rain, the middle position detention tank and the end position detention tank can play the role of rainwater collection and utilization.

In general, the end position detention tank needs to be set centrally, so it is difficult to locate due to its large volume, but the operation management is relatively easy. Compared with the end position detention tank, the middle position detention tank can be set flexibly and dispersedly, so the location selection is relatively easy, but it increases the difficulty of operation management and puts forward higher requirements for the operation management of the drainage system $[14,15]$.

The off-line detention tank is easy to set up and control, but its pipelines are relatively complex. The on-line detention tank is generally located in the middle position of the system, which can reduce pollution and prevent waterlogging at the same time. The pollution control efficiency of the detention tank is also related to the CSO first flush and the layout of the detention tank. According to the relevant research, for the combined sewer system areas with obviously first flush, the efficiency of the off-line detention tank is higher than that of the on-line detention tank, and the efficiency of the on-line detention tank is higher in the area without first flush [3].

\subsection{Operation Mode of Detention Tank}

Due to the limited scale of the detention tank, when the CSO amount is too large, the detention tank can only store part of the overflow water, and the main goal of the detention tank is to reduce the overflow pollutants rather than the overflow amount. Therefore, the operation modes of the detention tank such as emptying, online monitoring, real-time control, increasing sedimentation treatment, etc. have a great impact on the control effect of CSO.

If the CSO detention tank can't be started in time or emptied timely, it usually lead to the unavailability in some overflow events, thus reducing the operation efficiency of the detention tank. Therefore, scientific regulation and operation of the CSO detention tank should be conducted scientifically to avoid such a situation as far as possible.
For some areas where the obvious first flush can be observed easily through continuous monitoring and research, the better control effect can be achieved by focusing on controlling the CSO at the initial overflow stage. In order to improve the control efficiency of CSO, online monitoring and real-time control of water quality can be adopted to effectively capture, store and treat the CSO in the period of high pollutant concentration, such as online monitoring of CSO by UV-Vis spectrum, controlling the detention tank according to the real-time monitoring data, or monitoring the turbidity of overflow wastewater to control the operation of the detention tank in real time to improve the reduction rate of CSO pollutants [12].

Some scholars put forward the optimal strategy of CSO detention tank according to the characteristics of drainage system outflow in rainy days. For the drainage system with relatively obvious first flush or poor settling performance, the off-line detention tank is used to store the initial overflow in order to reduce the pollution load. The storage-sedimentation tank is used for the drainage system which has nearly no first flush or has good pollutant sedimentation performance in the outflow, and the better pollution control effect can be achieved by combining sedimentation and storage [16].

\section{Summary}

This paper summarizes the design methods of CSO detention tanks adopted in the United States, Germany, Japan, Italy and some Chinese cities. The scale and control effect of the CSO detention tank are studied by model simulation, taking the combined sewer system catchment area of $\mathrm{L}$ pumping station in the Beijing old city as examples. Based on the result of this study, the correlation between design volume and control efficiency is obtained by simulating annual rainfall for many years or a typical year, and then the scale of detention tank is determined by comprehensive analysis of CSO control objectives, funds, site space and other factors in combination with local condition.

The main factors influencing the CSO detention tank scale and the improvement of pollutant control efficiency are summarized as follows: the control objective of CSO, the characteristics of rainfall and the selection of rainfall data, the transportation law of CSO pollutant, the interception multiple, the treatment capacity of sewer treatment plant, the site space conditions, investment, the layout and operation mode of the detention tank. The characteristics and working principles of each factor are analyzed, hoping to provide reference for the scientific designing of CSO detention tank and realize cost-effectively controlling $\mathrm{CSO}$ in cities of China.

\section{References}

[1] Che Wu, Tang Lei. Research on strategies of Urban combined sewer system reconstruction and overflow pollution control in China [J]. Water \& Wastewater, 2012, 48 (03); 1-5. 
[2] Code for design of outdoor wastewater engineering, GB 50318-2012.

[3] Paolo S. Calabro, Gaspare Viviani; Simulation of the operation of detention tanks. Water Research. 2006, 40; 83-90.

[4] Zhang Shanfa. Research on prevention technology of rainwater overflow pollution in combined sewer system [D]. Shanghai; Tongji University, 2006. DOI: 10.7666/d.y1031954.

[5] Cheng $\mathrm{Xi}$, Che Wu, Tang Lei, Yang Zheng. Analysis of combined sewer overflow control planning and development process of the US [J]. China Water Supply and Drainage. 2017 (06).

[6] Zhang Xudong, Huang Haiwei, Zeng Siyu, Dong Xin. Analysis of water pollution load sources in Kunming's main urban area and estimation of its emission reduction potential [J]. Water Supply and Sewerage, 2019, 55 (S1); 116-121 + 125.

[7] Jia Nan, Wang Wenliang, Che Wu, Li Junqi, Wang Ersong. Analysis of combined sewer overflow control standards in the US and its implications for China [J]. China Water \& Wastewater, 2019, 35 (07); 121-127.

[8] Combined sewer overflows (CSOs). NYC Department of Environment Protection. http://www.nyc.gov/html/dep/html/stormwater/combined_sew er_overflow.shtml. 2018.

[9] The Washington administrative code (173-245-020). Washington State Legislature. $\mathrm{http}$; //apps.leg.wa.gov/WAC/default.aspx?cite=173-245-020. 2018.
[10] Report to congress combined sewer overflows into the great lakes basin. U S Environmental Protection Agency. 2016.

[11] Tang Lei, Che Wu, Zhao Yang, Gong Yongwei. Study on the first flush and control strategy of combined sewer overflow [J]. Water \& Wastewater, 2014, 50 (05); 24-30.

[12] Tang Lei, Che Wu, Zhao Yang, et al. Systematic decision making on combined sewer system overflow pollution control. Water \& Wastewater, 2012. 38 (7); 28-33.

[13] Upaka Rathnayake, A. H. M. Faisal Anwar. Dynamic control of urban sewer systems to reduce combined sewer overflows and their adverse impacts [J]. Journal of Hydrology, 2019.

[14] Milad Taghipour, Samira Tolouei, Laurra Toloueirr, Michra Toloueir, Ahmad Shakibaeinia, Sarah Dorner. Normalized dynamic behavior of combined sewer overflow discharges for source water characterization and management $[\mathrm{J}]$. Journal of Environmental Management, 2019, 249.

[15] Chen Yan, Zhong Mingming. Discussion on the layout of rainwater storage tanks [C]. //China Urban Water Supply and Drainage Association. Proceedings of the 2008 China-Japan Water Environment Pollution Prevention and Restoration Symposium. 2008; 1-9.

[16] Li Tian, Zeng Yanjun, Gao Qiuxia. Discussion on the design scheme of rainwater detention tank of the drainage system along the Suzhou River [J]. Water \& Wastewater, 2008 (02); 42-46. 